\title{
An analysis of unofficial sanction of India from neo-colonialism perspective $^{1}$
}

\section{Bhuwaneswor Pant}

\begin{abstract}
This paper mainly analyses the unofficial sanction of India against Nepal from neocolonial perspectives. The paper argues that the sanction of India against Nepal has been the repercussion of colonial hangover of the former. India saw new constitution of Nepal through latter's inferiority to write democratic constitution. India as a postcolonial nation inherited the colonial culture from British rule. It has been almost seven decades that India got independence from British rule but in reality it couldn't escape from the colonial culture left by the British. The study has been conducted as library research reviewing the wide range of research, articles and reports. The study is qualitative in nature, which has incorporated the description, assessment, examine and comparative methods.
\end{abstract}

Key words: Colonial hangover; Neo-colonialism; Nepal-India; Unofficial sanction

\section{Introduction}

Nepal promulgated its new Constitution in 2015 but the Madhesi immigrants living in southern plains of the country and Janajatis, the ethnic minorities who considered themselves as marginalized groups, felt that they were being neglected by new constitution. The Madhesis, Tharus, and Janajatis argued that the Constitution promulgated by the Constituent Assembly (CA) has failed to accommodate their long standing demands. These include: demarcation of provincial boundaries on ethnic lines, establishment of two Madhesh provinces, proportional representation of ethnic groups in state agencies and parliament, equal political

\footnotetext{
${ }^{1}$ Cite this article as: Pant, B. (2020). Contemporary Research: An Interdisciplinary Academic Journal, vol. 4 (1)

Bhuwaneswor Pant, PhD scholar in Tribhuvan University, Nepal

Email: bhuwanesworp@gmail.com

Article history: Received on September 3; Accepted on October 3; Published on October 30

Peer reviewed under the authority of CRAIAJ, academic journal of Ghodaghodi Multiple Campus, Kailali, Nepal, with ISSN 2717-4611 (Print) and ISSN 2717-462X (Online).

(C) 2020 CRAIAJ
}

Full text of this article can be downloaded from www.craiaj.com and www.nepjol.info 
rights to persons to acquire citizenship by naturalization, and implementation of previous agreements between the state and dissenting groups, Janajatis/Madhesis (Nayak, 2015). These groups, Madheshi immigrants in particular, then blockaded the border points. However, government of Nepal accused India of deliberately worsening the embargo by not allowing vehicles to pass from check-points where no protests were held. Indian government denied this. The eastern and western part of Nepal were peaceful, and there was no vehicular movement of goods coming from India to Nepal because they were completely halted by the former (Dahal, 2018).

India started tightening the passage of Nepal bound goods carriers through all the entry points citing increasing violence in the bordering areas of Nepal from 23 September 2015. Indian armed security force deployed at the borders, Sashastra Seema Bal (SSB), personals stopped goods carriers at the Indian side. Out of the six entry points, Sunauli- Bhairahawa route is the major one through which on a regular day 300-400 goods carrier used to enter Nepal. But, on the 24th of September, only four vehicles entered Nepal from Sunauli (The Kathmandu Post, 2015). On September 25, the Indian authorities continued to stop Nepal bound goods carrier vehicles, LPG bullets and oil tankers at Nepal-India border. Issuing a press statement, the Indian Embassy in Kathmandu said that the reported obstructions to Nepal-bound cargo and freights were due to unrest, protests and demonstrations on the Nepali side (The Kathmandu Post, 2015). In fact, the region has been witnessing violent protests since August 9, 2015 and over 46 persons including 10 security personnel have so far been killed in various incidents (Nayak, 2015). Considering these events, it can be highly ascertained that the undeclared sanction was India's silent support to the Madhesh protests and a response from India to Nepal promulgating the constitution despite India's wishes to postpone it (Chand, 2018).

Sanctions have been long used in international relations. In simple terms, trying to define sanctions in the abstract has severe limitations. However, using the term sanction in a particular context can make sense, even when it overlaps with other tactics or strategies of economic statecraft, and when it has both instrumental and expressive effects (Dobson, 2002). According to the Oxford Dictionary, sanction is an official order that limits trade, contact, etc. with a particular country, in order to make it do something, such as obeying international law. Miroslav Nincic and Peter Wallensteen (1983) define economic coercion as "the imposition of economic pain by one government on another in order to attain some political goal. It is implemented,

Full text of this article can be downloaded from www.craiaj.com and www.nepjol.info 
or at least initiated, by political authorities who intervene in the 'normal' operation of economic relations. Hufbauer, Schott, Elliot \& Oegg (2005) define economic sanctions as "the deliberate, government-inspired withdrawal, or threat of withdrawal, of customary trade or financial relations. 'Customary' does not mean 'contractual'; it simply means levels of trade and financial activity that would probably have occurred in the absence of sanctions.

In most of the cases there is power politics behind the sanction. However, some sanctions are unique to their context and specific to the country or the region. Sanction as a part and parcel in the exercise of international diplomacy, most of the time it is imposed to influence or change the internal or external policies of the target country (Aryal, 2019). During the blockade, the target country undergoes hardship and its people suffer from basic needs.

This paper mainly analyses the unofficial sanction of India within the framework of neo-colonial perspectives. What is found here is that those countries which were oppressed during the colonial period are rising as the oppressors after the end of colonial era. They use different forms of operations including sanction (ibid.). Indian people once oppressed, assumed themselves as oppressor and behaved Nepalese people as oppressed. The unofficial sanction of Indian government has occurred as a continuity of Indian hegemony on Nepal since signing of Sugauly treaty on 1947AD.

\section{Theoretical perspectives on neo-colonialism}

The term 'neo-colonialism' was first coined by Kwame Nkrumah. Neo-colonialism is the worst form of imperialism: for those who practice it, it means power without responsibility, and for those who suffer it, it is exploitation without redress (Nkrumah, 1956). Predominantly neo-colonialism has no definite definition. It has western, Asian and African versions of the definitions. According to Halperin (2020), "Neo-colonialism is the control of less-developed countries by developed countries through indirect means." It is the 'indirect means' as the developed countries are dominating underdeveloped or developing countries indirectly by using colonial exploitation rules.

Colonialism and the oppression we suffer today in the Fourth World are not a part of our past, a haunting memory; they are our living present, the recurring reality of everydayness. The postcolonial viewpoint and method are redundant and unhelpful for the study of contemporary colonized nations' struggles for freedom (Aryal, 2017). 
Thinking societies colonized by the postcolonial nations and their anti-colonial struggles through a postcolonial frame is impossible. Postcolonial nations' colonialism is more atrocious than settler colonialism the colonization of marginal or indigenous groups by others (ibid.). Settler colonialism occurs within a nation-state, so the settler bears some responsibilities and obligations. Postcolonial nations are free from such national considerations (ibid.). Some methodological problems seem challenging. The primary challenge is that there does not exist a practice of creating poetry and novel-writing about postcolonial nations' colonialism (Ibid)).

Altbach (1995) says that "Neo-colonialism is partly a planned policy of advanced nations to maintain their influence in developing countries, but it is also simply a continuation of past practices. Fanon (1952) argues that colonized people have been indoctrinated to believe in their own inferiority and to respect and imitate the culture and customs of the colonizing nation. Fanon (1952) explains, "Every colonized People in other words, every people in whose soul an inferiority complex has been created by the death and burial of its local cultural originality-finds itself face to face with the language of the civilizing nation; that is, with the culture of the mother country. The colonized is elevated above his jungle status in proportion to his adoption of the mother country's cultural standards" (Miller, 2014).

Fanon (1952) argues that the structures established by former colonial powers continue to exist in post-colonial nations. Neo-colonialism describes the ways in which colonizing powers cease to exert political control and domination but continue to influence a former colony through economic and social factors. One way in which this occurs is through the mimicry of the colonizer by the formerly colonized people (Miller, 2014). One of the difficulties associated with newly independent nations is that they continue to respect and imitate the customs of the former colonial power because, in the mind of the formerly colonized individual, that nation still represents the height of learning, technology, civilization, and economic power (ibid.). Even after the official end of colonialism, the impact of years of oppression and subjugation continues to leave a mark on a people group. For years they hear that they are inferior to the superior, civilizing, colonial power, and those false ideas do not easily dissipate. As a result, people continue to imitate the culture of the former colonizing power (ibid.).

As the colonialist power realizes it is impossible to continue its imperialistic rule of a country, it focuses instead on instilling its own culture and values in the new 
leaders of the country, the educated elites, and the colonized intellectuals (Fanon, 1963).The colonialist power's primary concern is instilling its own values in the rising leaders, the educated elite. Fanon notes that colonized natives "in order to assimilate and experience the oppressor's culture" must cease to critically consider or evaluate the structures established by the colonizer (Fanon, 1963). The colonized native must adopt "the forms of thought of the colonialist bourgeoisie" if he is to be accepted in the colonialist system (Fanon, 1963). In this way, colonialism produces an elite group of natives who imitate the customs of the colonial power and who cease to question the system of which they are a part.

\section{Analysis}

\section{Indian neo-colonialism on Nepal}

When India gained liberation from the rule of the British Empire in 1947, it was hoped that the new nation would provide the region with economic stability, border security, and a model of democratic politics to countries under the grip of tyrannical domestic regimes However, the opposite result emerged when India imitated and perpetuated the practices of its colonial master (Aryal, 2017). India has attempted to create structures to exploit the resources of neighbouring countries, inciting internal conflicts and destabilizing those countries, feeding authoritarian regimes for its own benefit, and taking advantage of the weak or absent democratic institutions in newly independent countries (ibid.). The oppressed, when liberated, has aspired to become a new oppressor.

The revival of India's old colonial desire under the new incarnation of the British Raj can be witnessed in Jawaharlal Nehru, the first prime minister of the newly independent republic who visited Nepal in 1959. When he saw gorgeous, snow-capped Himalayan peaks smiling like the rows of his own white teeth, he felt a mystic union with the Himalayas and recalled his ancestor's claim that the Himalayas are the northern border of Bharatbarsha, the Indian civilization (ibid.). Just four years later, during an intense border dispute with China in 1963, Nehru wrote a letter to Chinese Prime Minister Chou En-lai claiming the Himalayas as India's northern border, citing Hindu scriptures as evidence: "This northern frontier of India is for much of its length the crest of the Himalayan ranges. The Himalayas have always dominated Indian life, just as they have dominated the Indian landscape (ibid). 
Nehru and his home minister Sardar Ballavbhai Patel then conceived the expansionist ambition to annex Nepal. Nehru tried to become the new emperor, subduer, and sovereign of those smiling Himalayas in the north. However, the situation was quite unfavourable for a recently independent nation to colonize another newly founded nation. That would tarnish India's pro-democracy, anti-imperialist, anti-colonial image.

The Indian Empire, though, never accepted the autonomy of Nepal, except in treaties and speeches. It regards Nepal as a part of Bharatbarsha. This colonial desire has emerged not only from historical forces but also from India's modern need for vast natural resources, including waters from the Himalayas vital for the irrigation of the Bihar state (Aryal, 2017). The Indian Empire also wants to expand its market in Nepal and prevent its market from being reduced or outperformed by the Chinese goods. India wants to import precious herbs and teas from the Himalayas and export potatoes and tomatoes to Nepal. These goals resemble British exploitation of India (ibid.). Other countries in South Asia, including Nepal, are not only partners in India's commerce and the sources of its civilizations and languages; they are also its cultural references and the recurring image of its other. South Asian countries have helped define India as saviour, big brother, adult brother, and benevolent neighbour (ibid.).

\section{Indian sanction against Nepal as a reflection of colonial hangover}

When the British government left India in 1947, they not merely left the big infrastructure they had built in India to ease their rule, most importantly they also left the culture of dominating the inferior and the powerless (Perkovich, 2003). In other words, due to the mental and epistemic colonization of Indian people, they began to think of themselves as superior, civilized and powerful to validate civilizing mission of rulers in Nepal, a recreation and reimplementation of British policies in dominating the poor and powerless people (Aryal, 2019, p. 23). Nepal as a politically, economically and socially weaker has faced a lot of interventions after Indian independence. India tries to resemble with Britain wearing the mask for getting relief from its long history of suppression (ibid.).

The colonized and the slave perspective the issue of recognition as one which is critical to politics has also been debated by those who have been historically considered as "other." Based on the colonized and slave perspective, Fanon states that the dialectic of the politics of recognition needs to be viewed differently. The 
difficulty with the Hegelian dialectic of recognition is that the master wishes work from the slave and not recognition, whereas the slave wants to end his oppression. Thus, the feeling of inferiority leads to imitation of the culture of the colonizers. Regarding the behaviour of the colonized after declaration of independence Freire (2000) writes that the colonized in the search of independence, takes ways the colonizers power to dominate and suppress, they restore to the oppressors the humanity they had lost in the exercise of oppression. Accordingly, yesterdays oppressed have become today's oppressors, following the legacy of their former masters.

After the constituent assembly election in 2008, when India's direct political engagement in Nepal became unnecessary, India started bullying Nepal in order to secure its own interests over hydropower energy, development projects, business, and trade. India continued to tell Nepal what it should and should not do (Ojha, 2017). With a view to Nepal's constitution-making process, India officially emphasized its desire to see the country becoming a peaceful, stable, developed, and democratic state (GOI, 2015). As Nepal promulgated constitution on $20^{\text {th }}$ September 2015, the India released the statement showing its displeasure on it. The statement read (MoEF, 2015):

Throughout the process of Constitution making in Nepal, India has supported a federal, democratic, republican and inclusive Constitution. We note the promulgation in Nepal today of a Constitution.

... We urge that issues on which there are differences should be resolved through dialogue in an atmosphere free from violence and intimidation, and institutionalized in a manner that would enable broad-based ownership and acceptance. This would lay the foundation of harmony, progress and development in Nepal.

India's interference in the constitutional debate had the declared aim of encouraging the major parties to increase the document's legitimacy (ICG, 2016). The way that India interpreted the constitution of Nepal as a non-inclusive and discriminatory constitution devalued Nepal's long decade journey of making constitution by its people. Indian view on constitution on Nepal can be seen from the neo-colonization perspectives.

The Indian express issued seven points' amendments needs to be done in the new constitution of Nepal as quoting to the government of India on 24th September 
2015.These "amendments" have been conveyed to Nepal's leadership by the Indian government through official channels Ranjit Rae, India's ambassador to Nepal (Roy, 2015). The India Ministry of External Affairs said that the seven amendments are indispensable stating that these are the issues of concerns raised by the disgruntled Madhesi and Tharu groups (Kathmandu Post, 2015).

Any country cannot really propose the constitutional amendments to another country. India realized this latter and to escape from global scrutiny, disowned having made such proposal. But Nepalese political circle was actually pressed to fulfill these demands which the major party has refused. To avoid further pressure from India, they did not agree to Indian foreign secretary S. Jayashankar's call for the postponement of the new constitution. In response to the disagreement came the economic blockade (Khanal, 2015).

The proposed amendments in the constitution can also be analyzed through 'binary opposition relation' between colonized and colonizers as discussed by Said (1991). Said says that this kind of biased representation was further institutionalized and disseminated in such a way that ultimately the colonized themselves start to accept these stereotypes created by the colonizers. However, Fanon et al. (1963) say that the colonized world's feeling of inferiority leads to the imitation of the culture of the colonizer. India has found the constitution of Nepal non-inclusive (Muni, 2017) and a list sent for amending the constitutional provisions (Roy, 2015) to end the trouble at the border are some of the examples that India behaved Nepal as junior partner and trouble maker. There was a common understating among most of the respondents that India wants Nepal to use the same lens to see the other countries. Freire (2002) explains that colonizers do not see colonized as rational and independent actor, there is a perception that India does not see Nepal capable enough to cope the complex foreign relation of 21 st century though India was never a colonizer (Aryal, 2019). Given the Indian hegemony in Nepal's internal political affairs, unequal treaties, territorial encroachment and military (i.e., border security force) activities along the border and control over its natural resources, this suggests a continuation of colonialism, but in a new form often referred to as neo-colonialism. India, itself once under colonial rule, has now taken over this role (Karki \& KC, 2020). A country that has never been colonized can also become a neo-colony, which is independent in theory, but in reality, its economic system and political policy are directly under the influence of an external power. An example of a neo-colony is that 
it is coerced to carry out economic transactions and trade with the imperialist power, instead of enjoying the right of trading commodities in the international markets (ibid.). The actions and effects of certain remnant features and agents of the colonial era can be found in a given society long after the empire has gone out. Post-colonial studies have shown extensively that despite achieving independence, the influences of colonialism and its agents are still very much present in the lives of most former colonies (ibid.).

In the imperial ideology of brotherhood, the big brother assumes the role of protector, authority, and responsible guardian of younger siblings. In the name of caring for them, the big brother generally imposes his will on his younger ones (Aryal, 2017). This ideology undermines the principle that, no matter the size of nations, their sovereignty, integrity, and independence should be respected (ibid.). Indian foreign minister Susma Swaraj sought to transform the country's image as the big brother of Nepal and stated that India instead wanted to be Nepal's adult brother (ibid.). This terminology merely replaced one word with another and did not change India's interest and ambitions in domination. It is bizarre to observe how the Indian Empire deploys its ideology of brotherhood-the politics of the sameness (ibid.).The Indian empire, in fact, views its so-called younger siblings not as brothers but as its dependent others. This cultural perception permeates academia, politics, and culture. Even as the ideology of brotherhood is the main justification of colonization, the empire employs the colonial strategy of exclusion.

\section{Conclusion}

The unofficial sanction of India has been an attempt to coerce Nepal not to promulgate the constitution. Nepal promulgated the new constitution despite Indian pressure to delay promulgation date. India interpreted the constitution from the controversial angle and reasoned Nepal's inability and inferiority behind this. It prescribed certain amendments needed to be done in the new constitution breaching the diplomatic practices and tradition. This perception and response of India taking the new constitution Nepal can be framed within the reflection of colonial hangover. Nepal's relationship with India is strongly tinged by the British colonial era, although Nepal never became a formal colony. But relations in the post-1990 era have shown a consistent trend of increasing and mostly unwarranted Indian interference in Nepal's affairs (Ojha, 2015). 
India underestimated the capability and potentiality of Nepal to draft a democratic constitution as per will and aspiration of the people. Though, there have been some serious issues of marginalized and deprived sections of people needed to be properly addressed in the constitution, in principle the constitution opened the door for all ever in the constitutional history of Nepal. India misinterpreted new constitution of Nepal and exaggerated the political situation developed within Nepal on an unprecedented way and scale. India forgets its own history of constitutional development that the constitution of India has had more than 100 amendments since it was enacted. In fact, in the case of Nepal it couldn't wait and see. This exclusively substantiates Indian intention to continue her influence and empire over Nepal.

Both historically and conceptually, economic sanctions have been used to punish a transgression. Like sending a criminal to prison, the goal is not necessarily to rehabilitate the wrong-doer, but to punish him for his offense and to deter others from such wayward behaviour. Economic sanctions invoked for punitive ends also serve to define unacceptable behaviour, either unilaterally or multilaterally, and thus contributes to the establishment of internationally accepted standards of legitimate conduct (Brown, 1987). But Indian sanction against Nepal is beyond the international laws, provisions, treaties and conventions. India violated the international norms and values imposing sanction against closest neighbour having historical civilizational and cultural ties beside political and economic dimensions of relations. The new constitution of Nepal was unacceptable to India, despite latter's recommendation to postpone the constitution promulgation for the necessary changes to address Madhesh demands, former promulgated it. This caused annoyances to India that provoked her to punish Nepal for not listening former's concerns. India punished this behaviour of Nepal by imposing the unofficial sanction resulting severe humanitarian crises. It seems that Nepal seldom ignored Indian prescription in every political change, i.e., from regime changes to polity change. This was first time in the political history of Nepal that India's unfair endeavour to manipulate the constitution making process of Nepal in order to fulfill its vested interest was totally unsuccessful that provoked India to punish defiance through unofficial economic sanction.

\section{References}

Altbach, P. G. (1995). Literary colonialism: Books in the Third World. The postcolonial studies reader. In Bill Aschcroft, et al. (eds.). New York: Routledge, pp. 485-490.

Full text of this article can be downloaded from www.craiaj.com and www.nepjol.info 
Aryal, J. (2019). The nature and impacts of 2015 Indian unofficial blockade in Nepal. Master's Diss. Department of International Environment and Development Studies, Katharina Glaab

Aryal, Y. (2017). The Indian empire and its colonial practices in South Asia. Comparative Literature and Culture, 9, (2), pp1-10.

Brown, D. L. (1987). Lessons and policy considerations about economic sanctions. In David Leyton-Brown (Ed.), The Utility of international economic sanctions. New York: St. Martin's Press.

Chand, D. (2018). Trade embargo as a geopolitical tool: A case of Nepal-India trade relations. Polish Political Science Review, 6 (1), pp. 50-67.

Dahal, S. H. (2018). China-Nepal-India triangle: The dark side of Indo-Nepal relations. Kathmandu: Sangrila Pustak P. Ltd.

Dobson, A.P. (2002). US economic statecraft for survival 1933-1991: Of sanctions, embargoes and economic warfare. Rutledge: New York.

Fanon, F. (1952). Black skin white masks. London: Pluto Press.

Fanon, F. et al. (1963). The wretched of the earth. New York: Grove Press.

Freire, P. (2000). Pedagogy of the oppressed. New York: Bloomsbury Publishing.

GOI, (1950). Treaty of peace and friendship, July 31, 1950. Retrieved January 17 2016, from https://www.mea.gov.in/bilateraldocuments.htm?dtl/6295/Treaty_of_Peace_and_Friendship

Halperin , S. (2020). Neocolonialism. Retrieved from https://www.britannica.com/topic/neocolonialism

Hufbauer, G. C., Schott, J. J., Elliott, K.A. \& Oegg, B. (2007). Economic sanctions reconsidered. Peterson Institute for International Economics: United States of America

ICG, (2007). Nepal's constitutional process. Retrieved from https://nepalconflictreport.ohchr.org/files/docs/2007-02-26_report_icg_eng.pdf

Karki, K. K. \& KC, H. (2020). Nepal-India relations: Beyond realist and liberal theoretical. Journal of International Affairs, 3, pp.84-102.

Kathmandu Post, (2015). India wants seven amendments to Nepal's constitution: Confidential document. Retrieved from https://kathmandupost.com/national/2015/09/23/india-wants-sevenamendments-to-nepals-constitution-confidential 
Khanal, (2015). Nepal constitution: The status of India's seven-point amendment proposal. Retrieved from http://nepalforeignaffairs.com/nepal-constitution-thestatus-point-amendmentproposal/

Miller, R. (2014). Capitalistic Christians and educated elites: Fanonian theory and neo-colonialism in Ngugi WaThiong' o's A Grain of Wheat. English Seminar Capstone Research Papers. Retrieved from http://digitalcommons.cedarville.edu/english_seminar_capstone/26

Ministry of External Affairs, (2015b). Statement by external affairs minister. Retrieved from https://www.mea.gov.in/pressreleases.htm?dtl/25803/Statement+by+External+Affairs+Minister

Ministry of External Affairs, (2015c). Statement on the situation in Nepal. Retrieved from http:// www.mea.gov.in/press-releases.htm?dtl/25821/Statement on + the+situation+in+Nepal

Muni, S. D. (2017). Speech of S. D. Muni on importance of Nepal - India people to people relations at IIC 5.Retrieved from https://www.youtube.com/watch?v=OSXTzQ0TITI

Nayak, (2015). Post-constitution shivers in Nepal and India's response. Retrieved from https://idsa.in/idsacomments/PostConstitutionShiversinNepalandIndiasResp onse_nnayak_280915

Nincic, M. \& Wallensteen, P. (1983). Economic coercion and foreign policy. In Nincic, M. and Wallensteen, P. (eds.), Dilemmas of economic coercion: Sanctions in world politics. Praeger : New York.

Ojha, H. (2015). The India-Nepal crisis. Retrieved from https://thediplomat.com/2015/11/the-india-nepal-crisis/

Perkovich, G. (2003). Is India a major power? Washington Quarterly, 27(1), pp.129144.

Roy, S. (2015, September 24). Make seven changes to your constitution: India tells Nepal. Retrieved from http://www.indianexpress.com/article/world/ neighbours/make-seven-changes-to-your-constitution-address-madhesiconcerns-india-to-nepal/

Said, E. (1978). Orientalism. London: Vintage. 